\title{
Biochemical characterization of a mitochondrial-like organelle from Blastocystis sp. subtype 7
}

\author{
Correspondence \\ Nigel Yarlett \\ nyarlett@pace.edu
}

Received 22 February 2008

Revised 10 April 2008

Accepted 14 April 2008

\author{
Yelena Lantsman, ${ }^{1}+$ Kevin S. W. Tan, ${ }^{3}$ Mary Morada ${ }^{1}$ and Nigel Yarlett ${ }^{1,2}$ \\ ${ }^{1}$ Haskins Laboratories, Pace University, New York, NY 10038, USA \\ ${ }^{2}$ Department of Chemistry and Physical Sciences, Pace University, New York, NY 10038, USA \\ ${ }^{3}$ Laboratory of Molecular and Cellular Parasitology and Infectious Disease Programme, Department \\ of Microbiology, Yong Loo Lin School of Medicine, National University of Singapore, 117597, \\ Singapore
}

A mitochondrion-like organelle (MLO) was isolated from isotonic homogenates of Blastocystis. The organelle sedimented at $5000 \mathrm{~g}$ for $10 \mathrm{~min}$, and had an isopycnic density in sucrose of $1.2 \mathrm{~g}$ $\mathrm{ml}^{-1}$. Biochemical characterization enabled the demonstration of several key enzymes that allowed the construction of a metabolic pathway consisting of an incomplete Krebs cycle linked to the oxygen-sensitive enzymes pyruvate: $\mathrm{NADP}^{+}$oxidoreductase (PNO), acetate : succinate CoA transferase (ASCT) and succinate thiokinase (STK), which cumulatively are responsible for recycling $\mathrm{CoA}$ and generating ATP. The organelle differs from typical aerobic mitochondria in possessing an oxygen-sensitive $\mathrm{PNO}$ that can use $\mathrm{FAD}^{+}$or $\mathrm{FMN}^{+}$as electron acceptor but is inactive with $\mathrm{NAD}^{+}$, Spinacia oleracea ferredoxin or Clostridium pasteurianum ferredoxin. A gene with $77 \%$ sequence similarity to the PNO mitochondrion precursor cluster from Euglena gracilis $\mathrm{sp}[\mathrm{Q} 941 \mathrm{N5}$ ] was identified in the Blastocystis genome database. A second cluster with $56 \%$ sequence similarity to the pyruvate: ferredoxin oxidoreductase (PFOR) from Trichomonas vaginalis was also identified, which is in agreement with the concept that the PNO gene arose through the fusion of a eubacterial gene for PFOR with the gene for NADPH : cytochrome p450 reductase. Hydrogenase activity was not detected under the conditions used in this study. The Blastocystis oranelle therefore demonstrates significant biochemical differences from traditional mitochondria and hydrogenosomes, but possesses features of both. Based upon the results of this study, the Blastocystis organelle falls into the category of a MLO.

\section{INTRODUCTION}

The protozoon Blastocystis is an inhabitant of the intestinal tract of mammals and some reptiles. Blastocystis is the most frequently reported protozoon in the human intestinal tract (Lavier, 1952; Lee, 1991) and has been reported to cause intestinal disease in a number of cases, resulting in abdominal cramps, diarrhoea and significant discomfort (Weg et al., 1987). In some cases the parasite has been reported to cause acute illness (Russo et al., 1988; Vannatta et al., 1985) and can be life threatening when present in immunocompromised individuals (Prasad et al., 2000). Endoscopic and permeability studies of the intestine in a cohort study of Blastocystis-infected immunocompetent individuals failed to find any significant intestinal

†Present address: The University of Moscow Medical School, Moscow, Russia.

Abbreviations: ASCT, acetate, succinate CoA transferase; CoA, coenzyme A; MLO, mitochondrion-like organelle(s); PEPCK, phosphoenolpyruvate carboxykinase; PFOR, pyruvate, ferredoxin oxidoreductase; PNO, pyruvate, $\mathrm{NADP}^{+}$oxidoreductase; STK, succinate thiokinase. inflammation or impairment of the intestinal permeability barrier (Zuckerman et al., 1994). Fresh Blastocystis isolates, though, have been demonstrated to cause significant cytopathology of Chinese hamster ovary cells ( $\mathrm{CHO}$ ), adenocarcinoma HT-29 cells and rat intestinal epithelia (IEC-6) cells in culture (Puthia et al., 2006; Walderich et al., 1998). Metronidazole, paromomycin and ketoconazole have been used as therapeutic agents with mixed success (Zierdt et al., 1983; Dunn \& Boreham, 1991; Haresh et al., 1999; Nanba et al., 2003). Although there have been some advances made concerning the morphology and cytochemistry of the organism, little is known of the biochemistry. The presence of mitochondrion-like organelles (MLO) has been inferred, based largely upon microscopic evidence (Zierdt et al., 1988); however, key mitochondrial proteins such as Krebs cycle enzymes and cytochromes were not detected (Zierdt, 1986; Zierdt et al., 1988). These studies were hampered by difficulties in obtaining large amounts of the organism and problems associated with obtaining pure organelles such as MLO, which tend to clump upon fractionation (Zierdt et al., 1988). Nasirudeen \& Tan (2004) described a method for the 
isolation of MLO from this organism and observed the presence of DNA in the organelles.

Adaptation to anaerobic environments has resulted in the evolution of modified energy-generating organelles, such as hydrogenosomes in the trichomonads (Lindmark \& Müller, 1973, 1974), rumen protists (Yarlett et al., 1981), rumen fungi (Yarlett et al., 1986) and protists inhabiting the cockroach hind gut (Akhmanova et al., 1998). Other recently described modified mitochondria include the mitosome of Entamoeba (Tovar et al., 1999), the cryptic organelle of Giardia sp. (Marti et al., 2003), the relict organelle in Cryptosporidium parvum (Keithly et al., 2005) and the microsporidians Antonospora locustae and Encephalitozoon cuniculi (Burri et al., 2006). These organelles have one or more of the following features in common with the mitochondrion - recognition of specific targeting sequences (Dacks et al., 2006), production of ATP (Embley et al., 2003; van Weelden et al., 2005) and ironsulfur cluster assembly (Tachezy et al., 2001) - leading to the suggestion that these organelles all arose from a common ancestor. In this study we demonstrate the presence of key mitochondrial enzymes in Blastocystis and show they are localized in organelles previously described as MLO.

\section{METHODS}

Culture and preparation of homogenates. Blastocystis isolate B, designated Blastocystis sp. group VII (Noël et al., 2005) or subtype 7 (Stensvold et al., 2007) in later phylogenetic or terminology standardization studies, respectively, was used. The parasite was grown in $10 \mathrm{ml}$ pre-reduced Iscove's modified Dulbecco's medium (IMDM) supplemented with $10 \%$ heat-inactivated horse serum. Cultures were incubated for $48 \mathrm{~h}$ in anaerobic jars using an Oxoid AneroGen pack at $37{ }^{\circ} \mathrm{C}$. Two-day-old cultures were centrifuged at $1600 \mathrm{~g}$ for $10 \mathrm{~min}$, washed once in a buffer consisting of $30 \mathrm{mM}$ potassium phosphate, $74 \mathrm{mM} \mathrm{NaCl}, 0.6 \mathrm{mM} \mathrm{CaCl}_{2}$ and $1.6 \mathrm{mM} \mathrm{KCl}$, $\mathrm{pH} 7.4$ and resuspended in $50 \mathrm{mM}$ Tris/ $\mathrm{HCl}(\mathrm{pH} 7.2)$.

Fractionation. Cells were broken under a stream of nitrogen gas by 40 strokes in a $10 \mathrm{ml}$ Potter-Elvehjem tissue homogenizer at $4{ }^{\circ} \mathrm{C}$ in an isotonic buffer consisting of $200 \mathrm{mM}$ sucrose (pH 7.2) containing $30 \mathrm{mM}$ phosphate, $15 \mathrm{mM}$ mercaptoethanol, $30 \mathrm{mM} \mathrm{NaCl}, 0.6 \mathrm{mM}$ $\mathrm{CaCl}_{2}$, and $0.6 \mathrm{mM} \mathrm{KCl}$. The broken cells were diluted with isotonic buffer that had been degassed under vacuum and the air replaced with nitrogen before centrifugation at $500 \mathrm{~g}$ for $10 \mathrm{~min}$ using a Sorvall RC$2 \mathrm{~B}$. The supernatant was further fractionated by centrifugation to give a large granular fraction ( $5000 \mathrm{~g}$ for $10 \mathrm{~min}$ ), a small granular fraction $(25000 \mathrm{~g}$ for $20 \mathrm{~min}$ ) and a final supernatant. Density gradients were prepared from 15 and $65 \%(\mathrm{w} / \mathrm{w})$ sucrose in $10 \mathrm{mM}$ Tris/HCl buffer ( $\mathrm{pH} 7.2$ ), containing $0.7 \mathrm{mM}$ EDTA and $15 \mathrm{mM}$ mercaptoethanol. The large granular fraction (4 mg protein) and the small granular fraction ( $2 \mathrm{mg}$ protein) were carefully layered on top of the gradients and centrifuged in a $6 \times 12 \mathrm{ml}$ swing-out rotor (Beckman OTD 65 ultracentrifuge) at $4{ }^{\circ} \mathrm{C}$ for $30 \mathrm{~min}$ at $46000 \mathrm{~g}$. Fractions (approx. $2 \mathrm{ml}$ ) from the gradient were collected under nitrogen and assayed immediately for enzyme activity. The density of the fractions was determined using a refractometer.

\section{Enzyme analysis}

Unless stated otherwise, enzyme assays were performed under anaerobic conditions using buffers, substrates and cofactors that had the air removed under vacuum and replaced with nitrogen. Cuvette additions were made in an anerobic chamber (Coy Laboratories) and Blastocystis protein (40-60 $\mu \mathrm{g})$ was added to start the reaction by injection through a rubber septum.

(a) Enzymes characteristic of hydrogenosomes. With the exception of formate dehydrogenase, assays performed for these enzymes used $40 \mu \mathrm{g}$ Trichomonas vaginalis protein obtained as described by Lindmark \& Müller (1973), as a positive control. Hydrogenase (EC 1.12.7.2) and pyruvate : ferredoxin oxidoreductase (PFOR; EC 1.2.7.1) were assayed by measuring the change in absorbance at $600 \mathrm{~nm}$ due to the reduction of methyl viologen [extinction coefficient $(\varepsilon)=8.25 \mathrm{mM}^{-1} \mathrm{~cm}^{-1}$ ] as described by Lindmark \& Müller (1973). Hydrogenase was assayed using $100 \mathrm{mM}$ potassium phosphate ( $\mathrm{pH}$ 7.4), $20 \mathrm{mM}$ methyl viologen and $250 \mathrm{mM}$ 2-mercaptoethanol under a stream of hydrogen. PFOR was assayed using $100 \mathrm{mM}$ potassium phosphate ( $\mathrm{pH} 7.4$ ), $20 \mathrm{mM}$ methyl viologen, $250 \mathrm{mM} 2$ mercaptoethanol, $0.1 \%$ Triton X-100, $0.25 \mathrm{mM}$ coenzyme A (CoA) and $2.5 \mathrm{mM}$ pyruvate. Malic enzyme (EC 1.1.1.40) was assayed using the method of Lindmark \& Müller (1974) in $6 \mathrm{mM}$ triethanolamine (pH 6.8), $1 \mathrm{mM} \mathrm{NADP}{ }^{+}, 0.66 \mathrm{mM} \mathrm{MnCl}$ and $0.1 \%$ Triton X-100. The reaction was started by the injection of $33 \mathrm{mM}$ malate through a rubber septum and the change in absorbance at $340 \mathrm{~nm}(\varepsilon$ $\mathrm{NADP}^{+}=6.3 \mathrm{mM}^{-1} \mathrm{~cm}^{-1}$ ) measured. Succinate thiokinase (STK; EC 6.2.1.5) was assayed as described by Lindmark \& Müller (1974) in Tris/succinate buffer ( $\mathrm{pH} 7.4$ ), $0.1 \mathrm{mM} \mathrm{MgCl}_{2}, 1 \mathrm{mM} \mathrm{CoA}$ and $1 \mathrm{mM}$ ATP. The reaction was started by the addition of protein and the change in absorbance at $235 \mathrm{~nm}\left(\varepsilon\right.$ ATP $\left.=40 \mathrm{mM}^{-1} \mathrm{~cm}^{-1}\right)$ compared to controls lacking ATP. Formate dehydrogenase (EC 1.2.1.2) was determined by the method of Nanba et al. (2003). The assay contained $40 \mathrm{mM}$ phosphate buffer ( $\mathrm{pH} 7.2), 0.5 \mathrm{mM}$ sodium formate ( $\mathrm{pH} 7.0), 5 \mathrm{mM} \mathrm{NAD}^{+}$, and protein to start the reaction. The absorbance change at $340 \mathrm{~nm}\left(\varepsilon \mathrm{NAD}^{+}=6.3 \mathrm{mM}^{-1} \mathrm{~cm}^{-1}\right)$ was recorded for $10 \mathrm{~min}$ at $30^{\circ} \mathrm{C}$.

(b) Enzymes characteristic of mitochondria. With the exception of pyruvate: $\mathrm{NADP}^{+}$2-oxidoreductase (PNO), assays for this group of enzymes used $30 \mu \mathrm{g}$ rat liver homogenate (Fansler \& Lowenstein, 1969 ) as a positive control. PNO (EC 1.2.1.51) was determined in the forward direction using the method of Inui et al. (1987). The assay consisted of $100 \mathrm{mM}$ potassium phosphate ( $\mathrm{pH} 7.4$ ), $2.5 \mathrm{mM}$ pyruvate, $\mathrm{CoA}, 1 \mathrm{mM} \mathrm{NADP}{ }^{+}$. The change in absorbance at $340 \mathrm{~nm}$ was measured at $37^{\circ} \mathrm{C}$ for $10 \mathrm{~min}\left(\varepsilon \mathrm{NAD}^{+}=6.3 \mathrm{mM}^{-1}\right.$ $\left.\mathrm{cm}^{-1}\right)$. The activity of PNO was also determined by replacing $\mathrm{NADP}^{+}$with $1 \mathrm{mM} \mathrm{FAD}^{+}\left(\varepsilon \mathrm{FAD}^{+}=11.7 \mathrm{mM}^{-1} \mathrm{~cm}^{-1}\right.$ at $\left.446 \mathrm{~nm}\right)$, $1 \mathrm{mM} \mathrm{FMN}^{+}\left(\varepsilon \mathrm{FMN}^{+}=12.5 \mathrm{mM}^{-1} \mathrm{~cm}^{-1}\right.$ at $\left.450 \mathrm{~nm}\right), 0.5-5.0 \mathrm{mM}$ $\mathrm{NAD}^{+}\left(\varepsilon \quad \mathrm{NAD}^{+}=6.3 \mathrm{mM}^{-1} \mathrm{~cm}^{-1}\right.$ at $\left.340 \mathrm{~nm}\right), \quad 0.1-1.0 \mathrm{mg}$ Clostridium pasteurianum ferredoxin ( $\varepsilon 4 \mathrm{Fe}-4 \mathrm{~S}$ ferredoxin= $17.6 \mathrm{mM}^{-1} \mathrm{~cm}^{-1}$ at $\left.390 \mathrm{~nm}\right)$ or $0.1-1.0 \mathrm{mg}$ Spinacia oleracea ferredoxin $\left(\varepsilon 2 \mathrm{Fe}-2 \mathrm{~S}\right.$ ferredoxin $=10.8 \mathrm{mM}^{-1} \mathrm{~cm}^{-1}$ at $\left.425 \mathrm{~nm}\right)$ as electron acceptor. Citrate synthase (EC 2.3.3.1) was assayed under

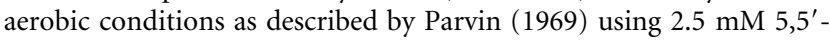
dithiobis-2-nitrobenzoic acid (DTNB) dissolved in $20 \mathrm{mM}$ Tris/HCl $(\mathrm{pH} 8.0)$ as indicator $\left(\varepsilon \mathrm{DTNB}=13.6 \mathrm{mM}^{-1} \mathrm{~cm}^{-1}\right.$ at $\left.414 \mathrm{~nm}\right)$. The reaction contained $0.1 \mathrm{M}$ Tris $(\mathrm{pH} 8.0), 0.25 \mathrm{mM}$ DTNB, $0.2 \mathrm{mM}$ oxaloacetate, $0.1 \mathrm{mM}$ acetyl-CoA and Blastocystis protein. The change in absorbance was monitored at $414 \mathrm{~nm}$ for $10 \mathrm{~min}$. Aconitase (EC 4.2.1.3) was determined by the method of Fansler \& Lowenstein (1969). The homogenate was activated by incubation under nitrogen for $30 \mathrm{~min}$ at $30{ }^{\circ} \mathrm{C}$ with a $1: 1$ mixture of protein and $10 \mathrm{mM}$ thiomalate containing $2 \mathrm{mM}$ ferrous ammonium sulfate in Tris ( $\mathrm{pH} 7.8$ ), previously made anaerobic. The assay contained $20 \mathrm{mM}$ Tris ( $\mathrm{pH} 7.6), 50 \mathrm{mM} \mathrm{NaCl}, 2 \mathrm{mM}$ cis-aconitate, and protein in a final volume of $1 \mathrm{ml}$. The change in absorbance was recorded at $240 \mathrm{~nm}$ ( $\varepsilon$ cis-aconitate $=3.5 \mathrm{mM}^{-1} \mathrm{~cm}^{-1}$ ) for $15 \mathrm{~min}$ at $37^{\circ} \mathrm{C}$. Isocitrate dehydrogenase $\mathrm{NADP}^{+}(\mathrm{EC}$ 1.1.1.42) was assayed using the coupled assay described by Cook \& Sanwal (1969). The assay 
contained $\quad 0.16 \mathrm{M}$ Tris/acetate $(\mathrm{pH} 7.6), \quad 0.18 \mathrm{mM}$ dichlorophenolindophenol $\left(\varepsilon=34.2 \mathrm{mM}^{-1} \mathrm{~cm}^{-1}\right.$ at $\left.600 \mathrm{~nm}\right), \quad 0.5 \mathrm{mM}$ $\mathrm{NADP}^{+}, 0.27 \mathrm{mM}$ AMP, $0.83 \mathrm{mM}$ isocitrate $(\mathrm{pH} \mathrm{7.6)}$ and protein to start the reaction. Blanks lacking enzyme were subtracted from the rate. The decrease in absorbance at $600 \mathrm{~nm}$ was measured for $10 \mathrm{~min}$. $\alpha$-Ketoglutarate dehydrogenase (EC 1.2.4.2) was assayed as described by Sanadi (1969), and contained $60 \mathrm{mM}$ phosphate buffer ( $\mathrm{pH} 7.6$ ), $0.10 \mathrm{mM}$ CoA, $35 \mathrm{mM}$ cysteine $(\mathrm{pH} 7.0), 0.35 \mathrm{mM} \mathrm{NAD}^{+}$ $\left(\varepsilon=6.3 \mathrm{mM}^{-1} \mathrm{~cm}^{-1}\right)$ and $0.5 \mathrm{mM} \alpha$-ketoglutarate. The absorbance change at $340 \mathrm{~nm}$ was monitored for $10 \mathrm{~min}$ after the addition of protein. Acetate:succinate CoA transferase (ASCT; EC 2.8.3.8) activity was using the radioactive method described by Van Hellemond et al. (1998), in a mixture containing $50 \mathrm{mM}$ succinate (pH 7.4), $1 \mathrm{mM}\left[1{ }^{14} \mathrm{C}\right]$ acetyl-CoA $(0.2 \mathrm{MBq}), 50 \mathrm{mM}$ Tris/HCl $(\mathrm{pH} 7.4), 10 \mathrm{mM} \mathrm{MgCl}_{2}$ and $0.05 \%$ (v/v) Triton X-100. The reaction was started by the addition of protein and incubated for $20 \mathrm{~min}$ at $30{ }^{\circ} \mathrm{C}$. The reaction was stopped with $10 \%$ trichloracetic acid and cooled on ice. The $\left[1-{ }^{14} \mathrm{C}\right]$ acetate was separated by HPLC using a reverse-phase C-18 Percosil column $(4.6 \times 250 \mathrm{~mm}), 10 \mu \mathrm{m}$ particle size (Perkin Elmer), with a linear gradient starting with $80 \%$ $0.1 \mathrm{M} \mathrm{NaH} \mathrm{PO}_{4}$ (pH 3.25) containing $8 \mathrm{mM}$ octanesulfonic acid changing to $100 \% \quad 0.1 \mathrm{M} \mathrm{NaH}_{2} \mathrm{PO}_{4}$ (pH 5.5) containing $8 \mathrm{mM}$ octanesulfonic acid and $75 \%(\mathrm{v} / \mathrm{v})$ methanol in $30 \mathrm{~min}$. Signals were recorded and integrated using a $\beta$-Ram model-2 radiometric detector (IN/US Inc.). Malate dehydrogenase (EC 1.1.1.37) was assayed by measuring the decrease in absorbance at $340 \mathrm{~nm}$ due to NADH oxidation $\left(\varepsilon \mathrm{NAD}^{+}=6.3 \mathrm{mM}^{-1} \mathrm{~cm}^{-1}\right)$ with oxaloacetate. The assay contained $50 \mathrm{mM}$ triethanolamine. $\mathrm{HCl}(\mathrm{pH} \mathrm{7.4}), 5 \mathrm{mM}$ EDTA, $0.12 \mathrm{mM}$ oxaloacetate ( $\mathrm{pH} 7.0), 0.15 \mathrm{mM} \mathrm{NADH}$, and was started by addition of protein (Englard, 1969). Fumarate hydratase (EC 4.2.1.2) was assayed under aerobic conditions as described by Genda et al. (2006) in $100 \mathrm{mM}$ phosphate buffer ( $\mathrm{pH} 7.6$ ), $50 \mathrm{mM}$ malate and protein to start the reaction. The absorbance change at $250 \mathrm{~nm}$ $\left(\varepsilon=1.45 \mathrm{mM}^{-1} \mathrm{~cm}^{-1}\right)$ was monitored for $10 \mathrm{~min}$. Succinate dehydrogenase (EC 1.3.99.1) was assayed using $3.8 \mathrm{mM}$ dichlorophenolindophenol $\left(\varepsilon=34.2 \mathrm{mM}^{-1} \mathrm{~cm}^{-1}\right.$ at $\left.600 \mathrm{~nm}\right)$, $50 \mathrm{mM}$ phenazine methosulfate, $20 \mathrm{mM} \mathrm{KCN}$, in $100 \mathrm{mM}$ potassium phosphate buffer ( $\mathrm{pH} 7.4$ ), and protein (Singer \& Kearney, 1963). Sodium succinate $(200 \mathrm{mM})$ was added to start the reaction and the absorbance at $600 \mathrm{~nm}$ monitored for $10 \mathrm{~min}$ at $37^{\circ} \mathrm{C}$.

(c) Cytosolic enzymes. Assays for this group of enzymes used $40 \mu \mathrm{g}$ of $T$. vaginalis protein obtained as described by Lindmark \& Müller (1973), as a positive control. Glyceraldehyde-3-phosphate dehydrogenase (EC 1.2.1.12) was assayed by measuring the change in absorption at $340 \mathrm{~nm}$ due to the reduction of $0.5 \mathrm{mM} \mathrm{NAD}^{+}$ $\left(\varepsilon=6.3 \mathrm{mM}^{-1} \mathrm{~cm}^{-1}\right)$ with $0.1 \mathrm{mM}$ glyceraldehyde 3-phosphate in $0.14 \mathrm{mM}$ phosphate buffer (pH 7.6) (Duggleby \& Dennis, 1974). Lactate dehydrogenase (EC 1.1.1.27) was assayed as described by Yarlett et al. (1986) using $25 \mathrm{mM}$ phosphate buffer (pH 7.4), $0.1 \mathrm{mM}$ NADH $\left(\varepsilon=6.3 \mathrm{mM}^{-1} \mathrm{~cm}^{-1}\right), 0.5 \mathrm{mM}$ pyruvate $(\mathrm{pH} 7.0)$. The absorbance change at $340 \mathrm{~nm}$ was monitored for $10 \mathrm{~min}$. Phosphoenolpyruvate carboxykinase (PEPCK; EC 4.1.1.32) activity was determined under aerobic conditions by the method of Fukuda et al. (2004) using $50 \mathrm{mM} \mathrm{NaHCO}, 5 \mathrm{mM} \mathrm{MnCl}_{2}, 10 \mathrm{mM}$ phosphoenolpyruvate (PEP), and $2 \mathrm{mM}$ GDP in $100 \mathrm{mM}$ imidazole buffer ( $\mathrm{pH}$ 7.2). The reaction was started by addition of protein and incubated at $37{ }^{\circ} \mathrm{C}$ for $30 \mathrm{~min}$, stopped by addition of $50 \mathrm{mM}$ EDTA and cooled to $4{ }^{\circ} \mathrm{C}$. The oxaloacetate formed was determined by measuring the absorbance change at $340 \mathrm{~nm}$ due to the addition of $0.2 \mathrm{mM}$ NADH $\left(\varepsilon=6.3 \mathrm{mM}^{-1} \mathrm{~cm}^{-1}\right)$ and 3 units of yeast malate dehydrogenase in $100 \mathrm{mM}$ imidazole buffer ( $\mathrm{pH}$ 7.2). Pyruvate kinase (EC 2.7.1.40) was assayed under aerobic conditions by measuring the ATP produced from ADP $(0.1 \mathrm{mM})$ in $80 \mathrm{mM}$ triethanolamine buffer ( $\mathrm{pH} 7.5$ ) containing $1.3 \mathrm{mM}$ EDTA, $2.0 \mathrm{mM}$ $\mathrm{MgSO}_{4}$ and 1.0 mM PEP. Protein was added to start the reaction and the ATP formed after 15 min was quantified using a luminometer and $0.1 \mathrm{mg}$ firefly luciferase (Boyer, 1962).

(d) Enzymes characteristic of lysosomes. Assays for this group of enzymes used $30 \mu \mathrm{g}$ rat liver homogenate (Fansler \& Lowenstein, 1969 ) as a positive control. $\alpha$-Galactosidase (EC 3.2.1.22) was assayed under aerobic conditions by measuring the hydrolysis of $0.1 \mathrm{mg} o$ nitrophenyl $\alpha$-D-galactopyranoside $(\varepsilon$ for $p$-nitrophenol at $400 \mathrm{~nm}=17.5 \mathrm{mM}^{-1} \mathrm{~cm}^{-1}$ ) in $0.1 \mathrm{M}$ acetate buffer $(\mathrm{pH} \mathrm{4.5)}$ and protein for $10 \mathrm{~min}$ at $37{ }^{\circ} \mathrm{C}$. The reaction was stopped using $1 \mathrm{ml}$ $1 \mathrm{M}$ borate ( $\mathrm{pH} \mathrm{10)}$ and the absorbance at $420 \mathrm{~nm}$ recorded (Borooah et al., 1961). $\alpha$-Mannosidase (EC 3.2.1.24) was determined under aerobic conditions using a fluorescent assay containing $10 \mathrm{mM}$ 4-methylumbelliferyl $\alpha$-D-mannopyranoside in $25 \mathrm{mM}$ sodium acetate $(\mathrm{pH} 4.0)$ and protein for $10 \mathrm{~min}$ at $37^{\circ} \mathrm{C}$. The assay was stopped with $2 \mathrm{ml} 0.25 \mathrm{M}$ glycine/ $\mathrm{KOH}$ (pH 10.3) and the fluorescence determined using an excitation wavelength of $355 \mathrm{~nm}$ and an emission wavelength of $460 \mathrm{~nm}$ and compared to a 4-methylumbelliferone standard (Prence \& Natowicz, 1992).

Protein determination. Protein was determined by the Lowry method.

\section{RESULTS}

\section{Enzyme analysis}

In an attempt to characterize the MLO from Blastocystis, whole-cell extracts and subcellular fractions were examined for activity of enzymes characteristic of mitochondria, hydrogenosomes and other MLO. Two of the enzymes characteristic of hydrogenosomes, PFOR and hydrogenase, were undetectable in whole-cell extracts of Blastocystis

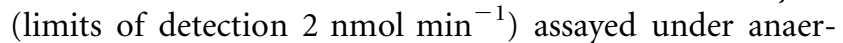
obic conditions and using a $\mathrm{pH}$ of 5.4-7.6. Using $T$. vaginalis as a positive control, the activity of these enzymes was consistent with the published specific activities (Lindmark \& Müller, 1973). Malic enzyme was detected using $\mathrm{NADP}^{+}$as electron acceptor with a specific activity consistent with that found in other organisms (Lindmark et al., 1989; Yarlett et al., 1981). The activity of this and other $\mathrm{NAD}^{+}$- and $\mathrm{NADP}^{+}$-utilizing enzymes was consistently higher when assayed under anaerobic conditions (described in Methods) due to recycling of the reduced nucleotide by NADH/NADPH oxidase. The activity of $\mathrm{NAD}^{+}$- and $\mathrm{NADP}^{+}$-utilizing enzymes presented in Table 1 were therefore determined under an oxygen-free atmosphere. The activity of an enzyme converting pyruvate to acetyl-CoA was detected in Blastocystis extracts using $\mathrm{NADP}^{+}$as an electron acceptor. The enzyme was characterized based upon substrate and cofactor requirements to be PNO (EC 1.2.1.51). The Blastocystis PNO could use $\mathrm{FAD}^{+}(5 \mathrm{mM})$ or $\mathrm{FMN}^{+}(5 \mathrm{mM})$ as an electron acceptor at $30 \%$ and $74 \%$, respectively, of the rate observed with $\mathrm{NADP}^{+}(1 \mathrm{mM})$. The enzyme was, however, inactive using $0.5-5.0 \mathrm{mM} \mathrm{NAD}{ }^{+}, 0.1-1.0 \mathrm{mg}$ Clostridium pasteurianum (4Fe-4S) or 0.1-1.0 mg Spinacia oleracea $(2 \mathrm{Fe}-2 \mathrm{~S})$ ferredoxin as electron acceptor. The enzyme was $100 \%$ inhibited by incubation under a stream of air for $5 \mathrm{~min}$, and $60 \%$ inhibited by incubation under a 
Table 1. Activity of enzymes in homogenates of Blastocystis

Enzymes were assayed as described in Methods. ND, No detectable activity within the limits of detection stated in Results. MLO, SGF and cytosol indicate activity recovered in the fractions identified as the mitochondria-like organelle, small granular fraction and cytosolic, respectively. Genomic information was obtained from the Blastocystis genome database (http://pepdbpub.bcm.umontreal.ca/pathway//BH/ server.html). Activity is presented as the mean \pm SD of triplicate determinations. One unit of enzyme activity represents 1 nmol substrate converted to product in 1 min. SDH, succinate dehydrogenase; GPDH, glyceraldehyde-3-phosphate dehydrogenase.

\begin{tabular}{|c|c|c|c|c|}
\hline Enzyme & $\begin{array}{l}\text { Activity [units } \\
(\text { mg protein })^{-1} \text { ] }\end{array}$ & Gene ID & Gene name & Localization \\
\hline${ }^{*}$ Malic enzyme (EC 1.1.1.40) & $28.9 \pm 1.7$ & & & MLO \\
\hline${ }^{\star} \mathrm{PNO}(\mathrm{EC}$ 1.2.1.51) & $82.4 \pm 6.1$ & BHL00002376/BHL00001250 & $\mathrm{PNO} / \mathrm{Pyr} \mathrm{fd} / \mathrm{fld}$ oxred & MLO \\
\hline $\begin{array}{l}\text { *ASCT (EC 2.8.3.8) acetyl-CoA hydrolase/ } \\
\text { transferase related cluster }\end{array}$ & $50.8 \pm 5.3$ & BHL00000444/BHL00000306 & ACHT & MLO \\
\hline${ }^{\star}$ STK (EC 6.2.1.5) & 317. \pm 11 & BHL00000088/BHL00000825 & SUCLA2 & MLO \\
\hline${ }^{*} \alpha$-Ketoglutarate dehydrogenase (EC 1.2.4.2) & $29.8 \pm 4.9$ & & & MLO \\
\hline $\begin{array}{l}\text { Dihydrolipoamide DH-related cluster (EC } \\
\text { 1.8.1.4) }\end{array}$ & & BHL00001496 & & \\
\hline Dihydrolipoyl DH-related cluster & & BHL00001057 & & \\
\hline${ }^{*}$ Isocitrate dehydrogenase (EC 1.1.1.42) & $5.47 \pm 0.1$ & & & MLO \\
\hline${ }^{\star}$ Aconitase (EC 4.2.1.3) & $8.26 \pm 0.7$ & & & MLO \\
\hline Fumarate hydratase (EC 4.2.1.2) & $0.30 \pm 0.1$ & $\begin{array}{l}\text { BHL00001701/BHL00001685/ } \\
\text { BHL00001095 }\end{array}$ & fumB & Cytosol \\
\hline & & BHL00001165/BHL00001811 & fumC & \\
\hline${ }^{*}$ Malate dehydrogenase (EC 1.1.1.37) & $14.0 \pm 1.8$ & BHL00002139 & MDHM & Cytosol \\
\hline PEPCK (EC 4.1.1.49) & $2.64 \pm 0.6$ & BHL00001570/BHL00002324 & pckA & Cytosol \\
\hline Pyruvate kinase (EC 2.7.1.40) & $26.8 \pm 3.2$ & & & Cytosol \\
\hline${ }^{\star}$ Lactate dehydrogenase (EC 1.1.1.27) & $16.0 \pm 1.7$ & & & Cytosol \\
\hline${ }^{\star} \mathrm{GPDH}(\mathrm{EC} 1.2 .1 .12)$ & $11.4 \pm 2.3$ & & & Cytosol \\
\hline${ }^{\star}$ Formate dehydrogenase (EC 1.2.1.2) & $3.56 \pm 0.8$ & & & Cytosol \\
\hline${ }^{\star}$ PFOR (EC 1.2.7.1) & ND & BHL00001771 & porA & \\
\hline${ }^{\star}$ Hydrogenase (EC 1.12.7.2) & ND & & & \\
\hline Citrate synthase (EC 2.3.3.1) & ND & & & \\
\hline $\begin{array}{l}{ }^{*} \text { Succinate dehydrogenase (EC 1.3.99.1) } \\
\text { SDH ubiquinone cluster (EC 1.3.5.1) }\end{array}$ & ND & BHL00001490/BHL00001794 & SDHfp/DHSA & \\
\hline$\alpha$-Galactosidase (EC 3.2.1.22) & 23.5 & BHL00002178 & AGAL & SGF \\
\hline$\alpha$-Mannosidase (EC 3.2.1.24) & 17.9 & $\begin{array}{l}\text { BHL00000629; BHL00001607; } \\
\text { BHL00003253 }\end{array}$ & $\begin{array}{l}\text { MAN2B1; MA2B1; } \\
\text { MANA }\end{array}$ & SGF \\
\hline
\end{tabular}

${ }^{\star}$ Enzymes assayed under oxygen-free conditions as described in Methods.

stream of $\mathrm{CO}_{2}$ for 5 min compared to controls measured under $\mathrm{N}_{2}$. The enzyme activity could also be determined using methyl viologen as electron acceptor, which resulted in $30 \%$ of the activity obtained using $0.1 \mathrm{mM} \mathrm{NADP}^{+}$. The acetyl-CoA formed by PNO was converted to acetate by ASCT (EC 2.8.3.8). The activity of the Blastocystis ASCT was confirmed using extracts of the procyclic stage of Trypanosoma brucei brucei as positive control. The presence of some of the enzymes characteristic of the Krebs cycle were determined using whole-cell extracts of Blastocystis and compared to a rat liver homogenate as a positive control. Citrate synthase (EC 2.3.3.1) and succinate dehydrogenase (EC 1.3.99.1) were not detected using a $\mathrm{pH}$ range of 5.7-7.6 (limits of detection $2 \mathrm{nmol} \mathrm{m^{-1 }}{ }^{-1}$ ). However, other Krebs cycle enzymes were present at levels comparable to control cells; aconitase (EC 4.2.1.3), isocitrate dehydrogenase (EC 1.1.1.42), $\alpha$-ketoglutarate dehydrogenase (EC 1.2.4.2), STK (EC 6.2.1.5), fumarate hydratase (EC 4.2.1.2) (Table 1), enabling construction of a partial pathway leading from the conversion of citrate to succinyl-CoA (Fig. 1).

\section{Subcellular localization}

Sedimentation of Blastocystis using increasing centrifugal force to produce a large granular fraction $(5000 \mathrm{~g}$ for $10 \mathrm{~min})$, a small granular fraction (25000 $\mathrm{g}$ for $20 \mathrm{~min}$ ) and a non-sedimentable fraction was performed under strict anaerobic conditions. The subcellular fractions were analysed for activity of the enzymes (Table 1). Integrity of organelles was confirmed by latency of enzyme activities using $2 \%$ Triton X-100. Malic enzyme, PNO and ASCT had $60 \%, 92 \%$ and $83 \%$ increased activity with the addition of Triton X-100. Based upon the ratio of the 


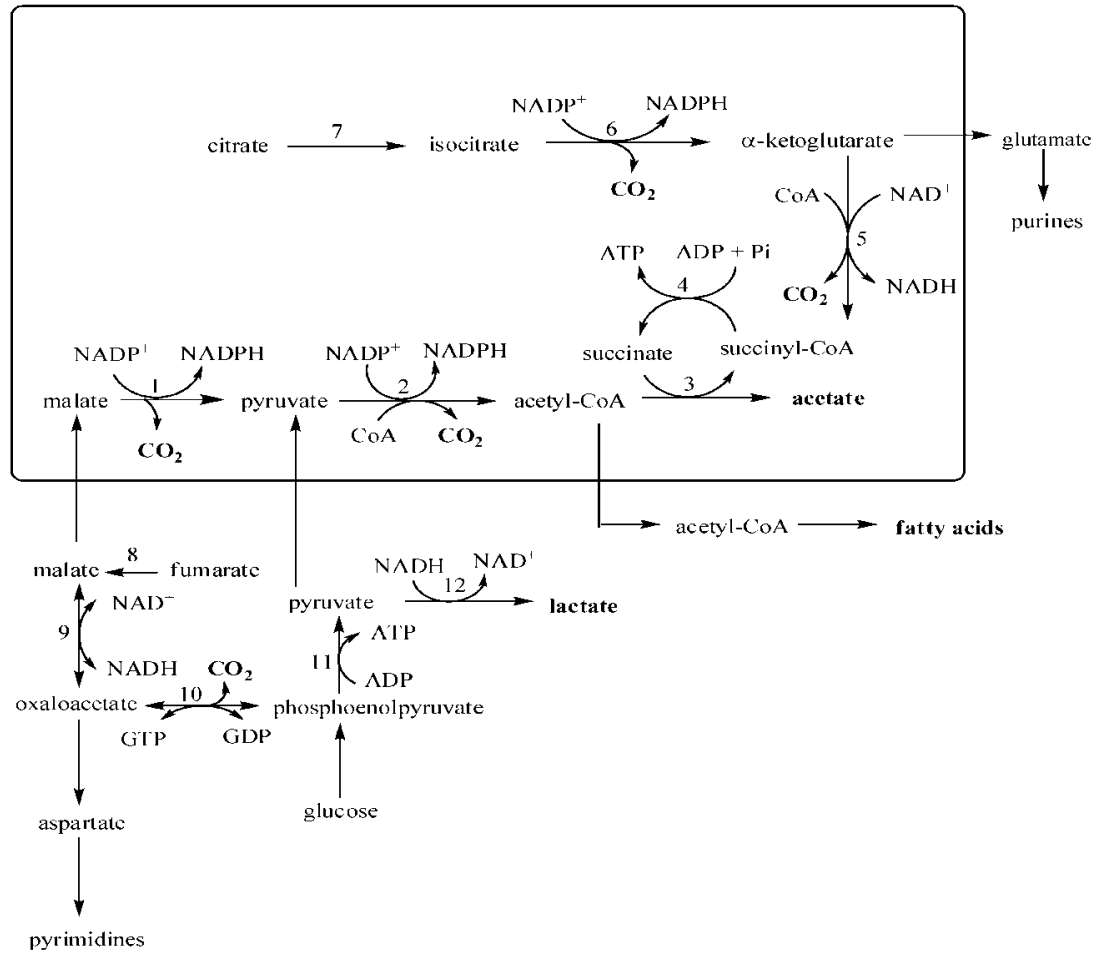

Fig. 1. Proposed pathway of metabolism in the MLO of Blastocystis. (1) Malic enzyme, (2) PNO, (3) ASCT, (4) STK, (5) $\alpha$-ketoglutarate dehydrogenase, (6) isocitrate dehydrogenase, (7) aconitase, (8) fumarate hydratase, (9) malate dehydrogenase, (10) PEPCK, (11) pyruvate kinase, (12) lactate dehydrogenase. Proposed end products of the pathway are in bold. Reactions shown within the box occur in the large granule fraction which contains the MLO. specific activity of the enzyme in the fraction to that in the homogenate (relative specific activity), it was concluded that malic enzyme, PNO, ASCT, STK, $\alpha$-ketoglutarate dehydrogenase, isocitrate dehydrogenase and aconitase localized to the large granular fraction (Fig. 2A-G), whereas PEPCK, malate dehydrogenase, fumarate hydratase, pyruvate kinase and lactate dehydrogenase localized to the non-sedimentable fraction (Fig. 2H-L). $\alpha$ Galactosidase and $\alpha$-mannosidase activity were detected in the small granular fraction which is typical of lysosomes (Fig. 2M, N). Isopycnic gradient centrifugation of the large granular fraction and assay of the enzymes malic enzyme, PNO, ASCT, STK, $\alpha$-ketoglutarate dehydrogenase, isocitrate dehydrogenase and aconitase localized to a band having a density of $1.20 \mathrm{~g} \mathrm{ml}^{-1}$ (Fig. 3A), which is the same density as that reported for hydrogenosomes and mitochondria (Hart \& Opperdoes, 1984; Woods et al., 1988). Isopycnic gradient centrifugation of the small granular fraction and assay of $\alpha$-galactosidase and $\alpha$-mannosidase resulted in these enzymes localizing to a band having a density of $1.16 \mathrm{~g} \mathrm{ml}^{-1}$ (Fig. 3B), typical of lysosomal organelles (Hart \& Opperdoes, 1984; Woods et al., 1988).

\section{DISCUSSION}

The results of this study demonstrate that the MLO from Blastocystis lack a typical pyruvate dehydrogenase; instead they possess an oxygen-sensitive PNO which produces acetyl-CoA from pyruvate. This enzyme has similar properties to that previously described for the pyruvatemetabolizing enzyme from the mitochondrion of Euglena gracilis (Inui et al., 1987) and Cryptosporidium parvum (Rotte et al., 2001). These biochemical findings are in agreement with a search of the Blastocystis EST database (http://pepdbpub.bcm.umontreal.ca/pathway//BH/server.html) that reveals the presence of a gene with $77 \%$ sequence identity to the PNO mitochondrion precursor cluster from E. gracilis sp[Q941N5] (accession number BHL00002376). The PNO gene from E. gracilis is believed to have arisen through fusion of a eubacterial gene for PFOR with the gene for NADPH cytochrome p450 reductase (Rotte et al., 2001). In agreement with these findings, a second cluster with $56 \%$ sequence identity to the PFOR cluster typical of T. vaginalis (accession number BHL00001771) was also found, although activity of this enzyme could not be demonstrated. In common with other PNOs, the enzyme was oxygen sensitive, being completely inactivated when cell-free extracts were exposed to air. The Blastocystis PNO was capable of transferring electrons to $\mathrm{FAD}^{+}$or $\mathrm{FMN}^{+}$at $30 \%$ and $74 \%$, respectively, of the rate observed with $\mathrm{NADP}^{+}$; several other electron acceptors, including $\mathrm{NAD}^{+}$and Clostridium or spinach ferredoxin, were inactive. In hydrogenosomes the electron acceptor is a 2 iron:2 sulfur ferredoxin (Gorrell et al., 1984), whereas in mitochondria the electrons are transferred from the $\mathrm{NADH}$ to the cytochrome chain, resulting in the formation of ATP (Krayl et al., 2007). The electron transport proteins in Blastocystis are unknown, but may be similar to the NADPH: cytochrome p450 reductase in Euglena and Cryptosporidium parvum (Rotte et al., 2001) or the flavoprotein: rhodoquinone complex as described 

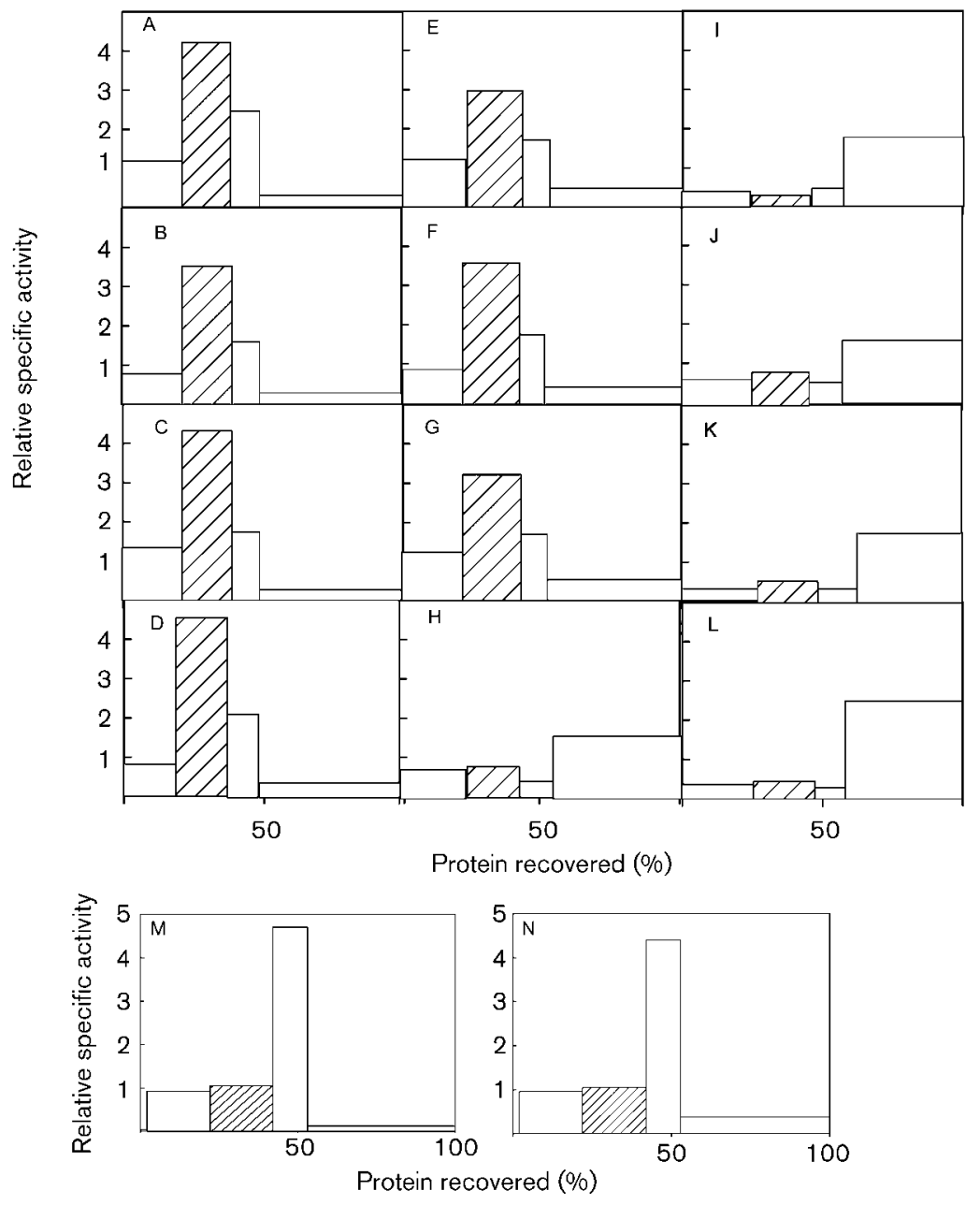

Fig. 2. Subcellular localization of enzymes in Blastocystis. Homogenates were subjected to differential centrifugation in anaerobic buffers with increasing $\boldsymbol{g}$-force from left to right. Enzymes were assayed as described in Methods. Relative specific activities (the ratio of the specific activity in fractions to that in the cell-free extract) are plotted against cumulative percentage of protein recovered in each fraction. Percentage recoveries (based on enzyme units in the cell-free extract) were: (A) PNO, 68\%; (B) malic enzyme, $84 \%$; (C) ASCT, $72 \%$; (D) aconitase, $74 \%$; (E) isocitrate dehydrogenase, $79 \%$; $(\mathrm{F}) \alpha$-ketoglutarate dehydrogenase, 81\%; (G) STK, 83\%; (H) fumarate hydratase, $84 \%$; (I) malate dehydrogenase, 79\%; (J) pyruvate kinase, 79\%; (K) PEPCK, $87 \%$; (L) lactate dehydrogenase, $78 \%$; (M) $\alpha$-galactosidase, $74 \%$; (N) $\alpha$ mannosidase, $68 \%$. in the anaerobic mitochondria of parasitic nematodes (Ma et al., 1993). The efficacy of metronidazole in the treatment of Blastocystis infections indicates the presence of lowpotential electron-acceptor proteins in this parasite. Typically, metronidazole reduction involves the transfer of electrons from pyruvate by the action of PFOR (Edwards, 1993). The ability of PNO to reduce metronidazole has not been definitively demonstrated but the enzyme may function in this capacity. It has been demonstrated that the electrons for metronidazole activation by $T$. vaginalis can originate from malate which is oxidatively decarboxylated by malic enzyme (Hrdy et al., 2005). The electrons released from malate reduce $\mathrm{NAD}^{+}$and are subsequently transferred to ferredoxin by the $\mathrm{NADH}$ : ferredoxin oxidoreductase activity of the NADH dehydrogenase module of mitochondrial respiratory complex I (Hrdy et al., 2004). Future studies will be aimed at identifying the terminal electron acceptor involved in metronidazole reduction by Blastocystis.

The presence of ASCT and STK results in the formation of acetate and ATP. In addition, an incomplete Krebs cycle was detected that results in the formation of succinyl-CoA. The proposed metabolic pathway (Fig. 1) retains key features of typical mitochondria and hydrogenosomes that couple the energy of the thioester bond of CoA to the generation of ATP. The inability to detect Krebs cycle enzymes in earlier seminal studies of Blastocystis by C. H. Zierdt (Zierdt, 1986; Zierdt et al., 1988) that paved the way for these and other studies of this parasite may be due to oxygen inactivation of enzymes involved in the pathway during processing of homogenates.

In common with other anaerobic protists (Lindmark et al., 1989), the fumarate hydratase of Blastocystis is of low activity and localized solely in the cytosol. There are two distinct classes of fumarate hydratase. Class I enzymes are of $\alpha$-proteobacterial origin and include fumA and fumB; these are homodimeric, thermolabile, iron-sulfur enzymes with a molecular mass of $120 \mathrm{kDa}$ (Woods et al., 1988; Gerbod et al., 2001). Class II enzymes are of archaeal origin (fumC) and are homotetrameric, thermostable, ironindependent enzymes with a molecular mass of $200 \mathrm{kDa}$ (Colombo et al., 1994; Gerbod et al., 2001). They are both present in eukaryotic cells, but are differentially localized with class I fumarate hydratase present in the mitochondria (Woods et al., 1988), whereas class II enzymes are localized in the cytosol (Suzuki et al., 1989). It is unknown what type of fumarate hydratase is present in Blastocystis, but a 
(A)
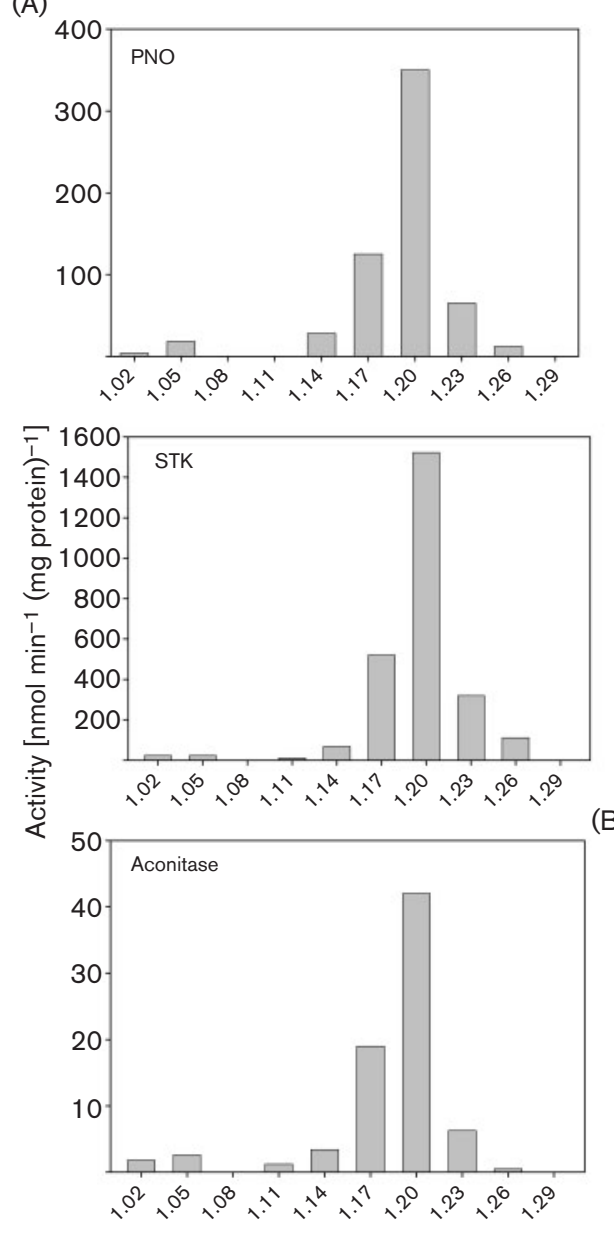
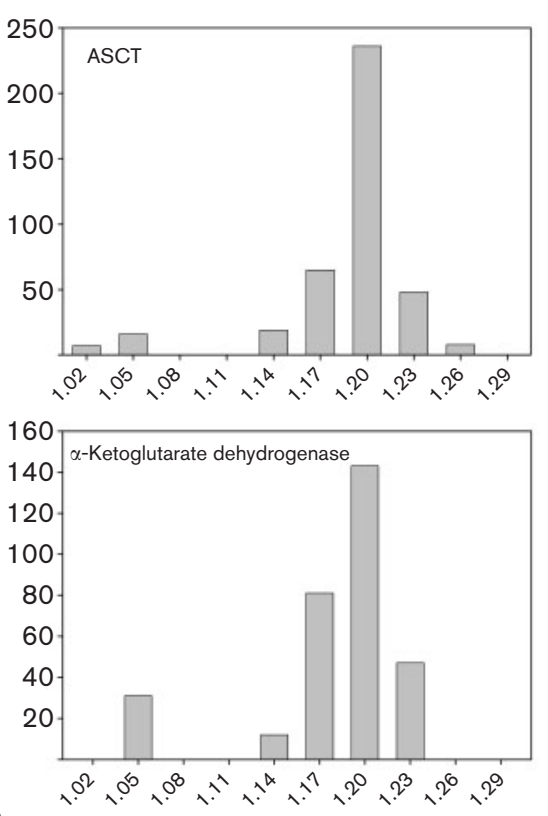

(B)

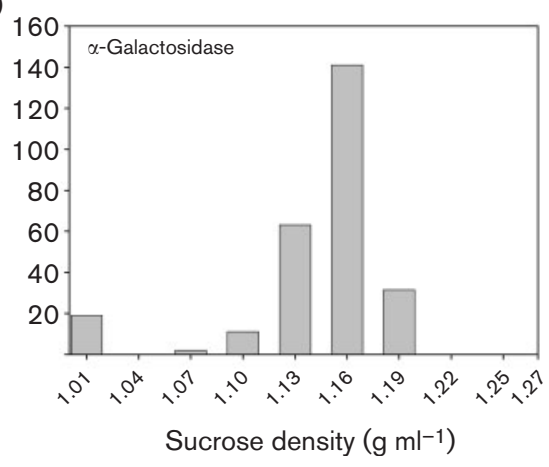

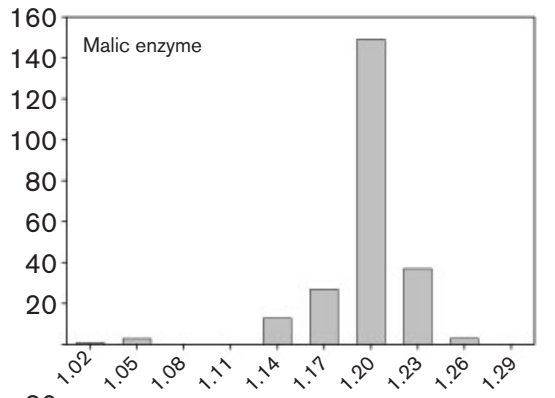
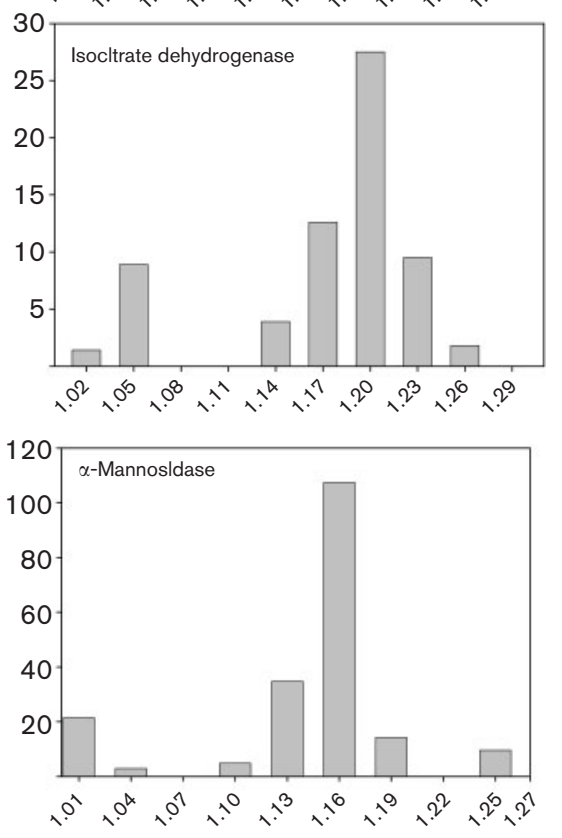

Fig. 3. Localization of sedimentable enzymes in fractions after isopycnic density fractionation in sucrose gradients. (A) The large granular fraction was layered onto a sucrose gradient $\left(1.02-1.29 \mathrm{~g} \mathrm{ml}^{-1}\right)$ as described in Methods. The direction of sedimentation was from left to right. The specific activities of enzymes in $\mathrm{nmol} \min ^{-1}$ (mg protein) ${ }^{-1}$ at their maxima, and percentage recoveries (in parentheses), were as follows: PNO, 380 (68\%); ASCT, 240 (73\%); malic enzyme, 152 (87\%); STK, 1540 (71\%); $\alpha$-ketoglutarate dehydrogenase, 143 (86\%); isocitrate dehydrogenase, 27.5 (79\%), and aconitase, 42 (73\%). Protein recovery was $102 \%$. (B) The small granular fraction was layered onto a sucrose gradient $\left(1.01-1.27 \mathrm{~g} \mathrm{ml}^{-1}\right)$. The direction of sedimentation was from left to right; the units of enzyme activity are as in $(A)$. The specific activities of enzymes defined as as $\mathrm{nmol} \mathrm{min}^{-1}$ (mg protein) $)^{-1}$ at their maxima, and percentage recoveries (in parentheses), were as follows: $\alpha$ galactosidase, 148 (81\%); $\alpha$-mannosidase, 110 (74\%). Protein recovery was $89 \%$.

search of the Blastocystis database (http://pepdbpub.bcm. umontreal.ca/pathway//BH/server.html) reveals the presence of several genes with homology to both class I fumarate hydratases (accession numbers BHL00001095, BHL00001685, BHL00001701) and class II fumarate hydratases (accession numbers BHL00001811, BHL00001165). The Trichomonas fetus fumarate hydratase has been shown to be of the class II type, leading to the suggestion that they have a different origin from those of mitochondria-containing cells (Gerbod et al., 2001).
The transformation of energy-rich substrates such as glucose to metabolic end products involves multiple steps that can vary considerably between different organisms. However, there are certain key points that are common to all, such as the steps involving electron transfer and the conservation of high-energy bonds for the ultimate formation of ATP. To this end a significant metabolic feature of the proposed pathway in the Blastocystis MLO is the transformation of pyruvate to acetate and the conservation of the high-energy thioester bond to form 
ATP. In common with trichomonad and Neocallimastix hydrogenosomes (Steinbuchel \& Müller, 1986; Yarlett et al., 1986), and mitochondria from the promastigote Leishmania mexicana, Leishmania infantum, Phytomonas sp. and procyclic Trypanaosoma brucei, as well as the parasitic helminth Fasciola hepatica (Van Hellemond et al., 1998), Blastocystis utilizes a two-step mechanism that couples succinate:succinyl CoA cycling with acetate formation to conserve the energy of the thioester bond to drive subcellular ATP formation (Fig. 1). This finding is consistent with the proposed common origin of hydrogenosomes and mitochondria (Martin, 1999). The absence of detectable succinate dehydrogenase activity suggests that the primary function of the partial Krebs cycle in Blastocystis is to provide precursors for the synthesis of amino acids or acetyl-CoA for fatty acid biosynthesis as occurs in E. gracilis (Hoffmeister et al., 2005). The presence of a partial Krebs cycle has been reported in the mitochondria from procyclic Trypanosoma brucei (Van Hellemond et al., 2005; van Weelden et al., 2005), which is proposed to function to export acetyl-CoA to the cytoplasm for fatty acid biosynthesis. The enzyme transferring the CoA moiety from acetyl-CoA to succinate in $T$. vaginalis hydrogenosomes is ASCT, which has been identified in the T. vaginalis genome (van Grinsven et al., 2008). The enzyme has high similarity to Saccharomyces cerevisiae acetyl-CoA hydrolase and Clostridium kluyveri succinyl-CoA : CoA-transferase (van Grinsven et al., 2008). A BLAST search (http://tbestdb.bcm.umontreal.ca/searches/ login.php) of the Blastocystis database using the ASCT sequence from T. vaginalis G3 (EST DS113258) reveals the presence of a protein with $78 \%$ identity (BHL 00000444) to the $T$. vaginalis protein.

The adaptability of the mitochondrion is evident from the literature and we therefore conclude that, despite the lack of cytochromes or other identifiable electrontransport proteins, the organelle from Blastocystis, which is characterized as a DNA-containing, double-membranebound structure with a partial Krebs cycle and an active ATP-generating metabolism, is best described as an MLO.

\section{ACKNOWLEDGEMENTS}

This work was supported in part by grants from the National Institutes of Health NCDDG AI40320 (N.Y.) and the Biomedical Research Council BMRC 05/1/21/19/378 (K. S. W. T.). Y. L. acknowledges the support of a travel award from Pace University. The authors thank Dr Thomas Gorrell for critical reading of the manuscript.

\section{REFERENCES}

Akhmanova, A., Voncken, F., van Alen, T., van Hoek, A., Boxma, B., Vogels, G., Veenhuis, M. \& Hackstein, J. H. (1998). A hydrogenosome with a genome. Nature 396, 527-528.

Borooah, J., Leaback, D. H. \& Walker, P. G. (1961). Studies on glucosaminidase. 2 . Substrates for $N$-acetyl- $\beta$-glucosaminidase. Biochem J 78, 106-110.
Boyer, P. D. (1962). Pyruvate kinase. In The Enzymes, pp. 95-113. Edited by P. D. Boyer, K. H. Lardy \& K. Myrback. New York: Academic Press.

Burri, L., Williams, B. A., Bursac, D., Lithgow, T. \& Keeling, P. J. (2006). Microsporidia mitosomes retain elements of the general mitochondrial targeting system. Proc Natl Acad Sci U S A 103, 1591615920.

Colombo, S., Grisa, M., Tortora, P. \& Vanoni, M. (1994). Molecular cloning, nucleotide sequence and expression of a Sulfolobus solfataricus gene encoding a class II fumarase. FEBS Lett 337, 93-98.

Cook, R. A. \& Sanwal, B. D. (1969). Isocitrate dehydrogenase (NADspecific) from Neurospora crassa. Methods Enzymol 13, 42-47.

Dacks, J. B., Dyall, P. L., Embley, T. M. \& van der Giezen, M. (2006). Hydrogenosomal succinyl-CoA synthetase from the rumen-dwelling fungus Neocallimastix patriciarum; an energy-producing enzyme of mitochondrial origin. Gene 373, 75-82.

Duggleby, R. G. \& Dennis, D. T. (1974). Nicotinamide adenine dinucleotide-specific glyceraldehyde 3-phosphate dehydrogenase from Pisum sativum. J Biol Chem 249, 167-174.

Dunn, L. A. \& Boreham, P. F. (1991). The in vitro activity of drugs against Blastocystis hominis. J Antimicrob Chemother 27, 507-516.

Edwards, D. I. (1993). Nitroimidazole drugs-action and resistance mechanisms. II. Mechanisms of resistance. J Antimicrob Chemother 31, 201-210.

Embley, T. M., van der Giezen, M., Horner, D. S., Dyal, P. S. \& Foster, P. (2003). Mitochondria and hydrogenosomes are two forms of the same fundamental organelle. Philos Trans R Soc Lond B Biol Sci 358, 191-201.

Englard, S. (1969). Extramitochondrial L-malate dehydrogenase of beef heart. Methods Enzymol 13, 123-129.

Fansler, B. \& Lowenstein, J. M. (1969). Aconitase from pig heart. Methods Enzymol 13, 26-30.

Fukuda, W., Fukui, T., Atomi, H. \& Imanaka, T. (2004). First characterization of an archaeal GTP-dependent phosphoenolpyruvate carboxykinase from the hyperthermophilic archaeon Thermococcus kodakaraensis KOD1. J Bacteriol 186, 4620-4627.

Genda, T., Watabe, S. \& Ozaki, H. (2006). Purification and characterization from Corynebacterium glutamicum. Biosci Biotechnol Biochem 70, 1102-1109.

Gerbod, D., Edgcomb, V. P., Noël, C., Vanacova, S., Wintjens, R., Tachezy, J., Sogin, M. L. \& Viscogliosi, E. (2001). Phylogenetic relationships of class II fumarase genes from trichomonads. Mol Biol Evol 18, 1574-1584.

Gorrell, T. E., Yarlett, N. \& Müller, M. (1984). Isolation and characterization of Trichomonas vaginalis ferredoxin. Carlsberg Res Commun 49, 259-268.

Haresh, K., Suresh, K., Khairul Anus, A. \& Saminathan, S. (1999). Isolate resistance of Blastocystis hominis to metronidazole. Trop Med Int Health 4, 274-277.

Hart, D. T. \& Opperdoes, F. R. (1984). The occurrence of glycosomes (microbodies) in the promastigote stage of four major Leishmania species. Mol Biochem Parasitol 13, 159-172.

Hoffmeister, M., Piotrowski, M., Nowitzki, U. \& Martin, W. (2005). Mitochondrial trans-2-enoyl-CoA reductase of wax ester fermentation from Euglena gracilis defines a new family of enzymes involved in lipid synthesis. J Biol Chem 280, 4329-4338.

Hrdy, I., Hirt, R. P., Dolezal, P., Bardonova, L., Foster, P. G., Tachezy, J. \& Embley, T. M. (2004). Trichomonas hydrogenosomes contain the $\mathrm{NADH}$ dehydrogenase module of mitochondrial complex I. Nature 432, 618-622. 
Hrdy, I., Cammack, R., Stopka, P., Kulda, J. \& Tachezy, J. (2005). Alternative pathway of metronidazole activation in Trichomonas vaginalis hydrogenosomes. Antimicrob Agents Chemother 49, 5033-5036.

Inui, H., Ono, K., Miyatake, K., Nakano, Y. \& Kitaoka, S. (1987). Purification and characterization of pyruvate: $\mathrm{NADP}^{+}$oxidoreductase in Euglena gracilis. J Biol Chem 262, 9130-9135.

Keithly, J. S., Langreth, S. G., Buttle, K. F. \& Mannella, C. A. (2005). Electron tomographic and ultrastructural analysis of the Cryptosporidium parvum relict mitochondrion, its associated membranes, and organelles. J Eukaryot Microbiol 52, 132-140.

Krayl, M., Lim, J. H., Martin, F., Guiard, B. \& Voos, W. (2007). A cooperative action of the ATP-dependent import motor complex and the inner membrane potential drives mitochondrial preprotein import. Mol Cell Biol 27, 411-425.

Lavier, G. (1952). Blastocystis spp. Ann Parasitol Hum Comp 27, 339-356. Lee, M. J. (1991). Pathogenicity of Blastocystis hominis. J Clin Microbiol 29, 2089.

Lindmark, D. G. \& Müller, M. (1973). Hydrogenosome, a cytoplasmic organelle of the anaerobic flagellate Tritrichomonas foetus, and its role in pyruvate metabolism. J Biol Chem 248, 7724-7728.

Lindmark, D. G. \& Müller, M. (1974). Biochemical cytology of anaerobic flagellates. II. Subcellular distribution of oxidoreductases and hydrolases in Monocercomonas sp. J Protozool 21, 374-378.

Lindmark, D. G., Eckenrode, B. L., Halberg, L. A. \& Dinbergs, I. D. (1989). Carbohydrate, energy and hydrogenosomal metabolism of Tritrichomonas foetus and Trichomonas vaginalis. J Protozool 36, 214-216.

Ma, Y.-C., Funk, M., Dunham, W. R. \& Komuniecki, R. (1993). Purification and characterization of electron-transfer flavoprotein: rhodoquinone oxidoreductase from anaerobic mitochondria of the adult parasitic nematode Ascaris suum. J Biol Chem 268 , 20360-20365.

Marti, M., Regos, A., Li, Y., Schraner, E. M., Wild, P., Muller, N., Knopf, L. G. \& Hehl, A. B. (2003). An ancestral secretory apparatus in the protozoan parasite Giardia intestinalis. J Biol Chem 278, 24837-24848.

Martin, W. (1999). A briefly argued case that mitochondria and plastids are descendents of endosymbionts, but that the nuclear compartment is not. Proc Biol Sci 266, 1387-1395.

Nanba, H., Takaoka, Y. \& Hasegawa, J. (2003). Purification and characterization of formate dehydrogenase from Ancylobacter aquaticus strain KNK607M, and cloning of the gene. Biosci Biotechnol Biochem 67, 720-728.

Nasirudeen, A. M. \& Tan, K. S. (2004). Isolation and characterization of the mitochondrion-like organelle from Blastocystis hominis. J Microbiol Methods 58, 101-109.

Noël, C., Dufernez, F., Gerbod, D., Edgcomb, V. P., DelgadoViscogliosi, P., Ho, L. C., Singh, M., Wintjens, R., Sogin, M. L. \& other authors (2005). Molecular phylogenies of Blastocystis isolates from different hosts: implications for genetic diversity, identification of species, and zoonosis. J Clin Microbiol 43, 348-355.

Parvin, R. (1969). Citrate synthase from yeast. Methods Enzymol 13, $16-19$.

Prasad, K. N., Nag, V. L., Dhole, T. N. \& Ayyagari, A. (2000), Identification of enteric pathogens in HIV-positive patients with diarrhea in northern India. J Health Popul Nutr 18, 23-26.

Prence, E. M. \& Natowicz, M. R. (1992). Diagnosis of alpha mannosidosis by measuring alpha mannosidase in plasma. Clin Chem 38, 501-503.

Puthia, M. K., Sio, S. W., Lu, J. \& Tan, K. S. (2006). Blastocystis ratti induces contact-independent apoptosis, F-actin rearrangement, and barrier function disruption in IEC-6 cells. Infect Immun 74, 4114-4123.

Rotte, C., Stejskal, F., Zhu, G., Keithly, J. S. \& Martin, W. (2001). Pyruvate: $\mathrm{NADP}^{+}$oxidoreductase from the mitochondrion of Euglena gracilis and from the apicomplexan Cryptosporidium parvum: a biochemical relic linking pyruvate metabolism in mitochondriate and amitochondriate protists. Mol Biol Evol 18, 710-720.

Russo, A. R., Stone, S. L., Taplin, M. E., Snapper, H. J. \& Doern, G. V. (1988). Presumptive evidence for Blastocystis hominis as a cause of colitis. Arch Intern Med 148, 1064.

Sanadi, D. R. (1969). $\alpha$-Ketoglutarate dehydrogenase from pig heart. Methods Enzymol 13, 52-55.

Singer, T. P. \& Kearney, E. B. (1963). Succinate dehydrogenase. In The Enzymes, pp. 383-445. Edited by P. D. Boyer, K. H. Lardy \& K. Myrback. New York: Academic Press.

Steinbuchel, A. \& Müller, M. (1986). Anaerobic pyruvate metabolism of Tritrichomonas foetus and Trichomonas vaginalis hydrogenosomes. Mol Biochem Parasitol 20, 57-65.

Stensvold, C. R., Suresh, G. K., Tan, K. S., Thompson, R. C., Traub, R. J., Viscogliosi, E., Yoshikawa, H. \& Clark, C. G. (2007). Terminology for Blastocystis subtypes - a consensus. Trends Parasitol 23, 93-96.

Suzuki, T., Sato, M., Yoshida, T. \& Tuboi, S. (1989). Rat liver mitochondrial and cytosolic fumarases with identical amino acid sequences are encoded from a single gene. J Biol Chem 264, 2581-2586.

Tachezy, J., Sanchez, L. B. \& Müller, M. (2001). Mitochondrial type iron-sulfur cluster assembly in the amitochondriate eukaryotes Trichomonas vaginalis and Giardia intestinalis, as indicated by the phylogeny of IscS. Mol Biol Evol 18, 1919-1928.

Tovar, J., Fischer, A. \& Clark, C. G. (1999). The mitosome, a novel organelle related to mitochondria in the amitochondrial parasite Entamoeba histolytica. Mol Microbiol 32, 1013-1021.

van Grinsven, K. W., Rosnowsky, S., van Weelden, S. W., Pütz, S., van der Giezen, M., Martin, W., van Hellemond, J. J., Tielens, A. G. \& Henze, K. (2008). Acetate: succinate CoA-transferase in the hydrogenosomes of Trichomonas vaginalis: identification and characterization. J Biol Chem 283, 1411-1418.

Van Hellemond, J. J., Opperdoes, F. R. \& Tielens, A. G. (1998). Trypanosomatidae produce acetate via a mitochondrial acetate: succinate CoA transferase. Proc Natl Acad Sci U S A 95, 3036-3041.

Van Hellemond, J. J., Opperdoes, F. R. \& Tielens, A. G. (2005). The extraordinary mitochondrion and unusual citric acid cycle in Trypanosoma brucei. Biochem Soc Trans 33, 967-971.

van Weelden, S. W. H., van Hellemond, J. J., Opperdoes, F. R. \& Tielens, A. G. M. (2005). New functions for parts of the krebs cycle in procyclic Trypanosoma brucei, a cycle not operating as a cycle. J Biol Chem 280, 12451-12460.

Vannatta, J. B., Adamson, D. \& Mullican, K. (1985). Blastocystis hominis infection presenting as recurrent diarrhea. Ann Intern Med 102, 495-496.

Walderich, B., Bernauer, S., Renner, M., Knobloch, J. \& Burchard, G. D. (1998). Cytopathic effects of Blastocystis hominis on Chinese hamster ovary $(\mathrm{CHO})$ and adenocarcinoma HT29 cell cultures. Trop Med Int Health 3, 385-390.

Weg, A. L., Soave, R. \& Jacobson, I. M. (1987). The significance of intestinal Blastocystis hominis infection. Gastroenterology 92, 1688.

Woods, S. A., Schwartzbach, S. D. \& Guest, J. D. (1988). Two biochemically distinct classes of fumarase in Escherichia coli. Biochim Biophys Acta 954, 14-26.

Yarlett, N., Hann, A. C., Lloyd, D. \& Williams, A. G. (1981). Hydrogenosomes in the rumen protozoan Dasytricha ruminantium Schuberg. Biochem J 200, 365-372. 
Yarlett, N., Orpin, C. G., Munn, E. A., Yarlett, N. C. \& Greenwood, C. A. (1986). Hydrogenosomes in the rumen fungus Neocallimastix patriciarum. Biochem J 236, 729-739.

Zierdt, C. H. (1986). Cytochrome free mitochondria of an anaerobic protozoan - Blastocystis hominis. J Protozool 33, 67-69.

Zierdt, C. H., Swan, J. C. \& Hosseini, J. (1983). In vitro response of Blastocystis hominis to antiprotozoal drugs. J Protozool 30, 332-334.
Zierdt, C. H., Donnolley, C. T., Muller, J. \& Constantopoulos, G. (1988). Biochemical and ultrastructural study of Blastocystis hominis. J Clin Microbiol 26, 965-970.

Zuckerman, M. J., Watts, M. T., Ho, H. \& Meriano, F. V.(1994). Blastocystis hominis infection and intestinal injury. Am J Med Sci 308, 96-101.

Edited by: J. Tachezy 